\title{
PEROLEHAN HAK ATAS TANAH YANG BERASAL DARI REKLAMASI PANTAI
}

\author{
Urip Santoso* \\ Departemen Hukum Administrasi, Fakultas Hukum Universitas Airlangga, Surabaya \\ Jalan Dharmawangsa Dalam Selatan, Surabaya, Jawa Timur 60222
}

\begin{abstract}
Status of reclamation coast land is state land. The status of land rights acquired privately held company is derived from reclamation building right or use right. The status of land rights acquired local government is the management right or use right. The status of land rights acquired by privat company that work with local government is building right or use right of management right. Land right derived from the reclamation acquired through the determination of the government in the from of decree granting right, namely those who do apply. Reclamation land titling state to the head of the national land agency republik of Indonesia.
\end{abstract}

Keywords: reclamation, state land, land right.

\section{Intisari}

Status tanah hasil reklamasi pantai adalah tanah negara. Status hak atas tanah yang diperoleh perusahaan swasta yang berasal dari reklamasi pantai adalah Hak Guna Bangunan atau Hak Pakai. Status hak atas tanah yang diperoleh Pemerintah Kabupaten/Kota adalah Hak Pakai atau Hak Pengelolaan. Status hak atas tanah yang diperoleh perusahaan swasta yang bekerja sama dengan Pemerintah Kabupaten/Kota adalah Hak Guna Bangunan atau Hak Pakai atas tanah Hak Pengelolaan. Hak atas tanah yang berasal dari reklamasi pantai diperoleh melalui Penetapan Pemerintah dalam bentuk Surat Keputusan Pemberian Hak yaitu pihak yang melakukan reklamasi pantai mengajukan permohonan pemberian hak atas tanah negara kepada Kepala Badan Pertanahan Nasional Republik Indonesia.

Kata Kunci: reklamasi, tanah negara, hak atas tanah.

\section{Pokok Muatan}

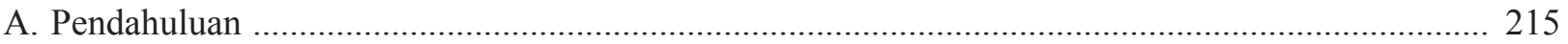

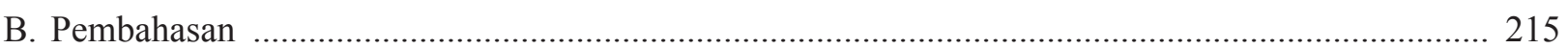

1. Status Hak Atas Tanah yang Dapat Diberikan kepada Pihak yang Melakukan Reklamasi Pantai

2. Cara Perolehan Hak Atas Tanah oleh Pihak yang Melakukan Reklamasi Pantai ....................... 221

C. Penutup 


\section{A. Pendahuluan}

Kegiatan pembangunan dapat dilakukan oleh lembaga negara, Kementerian, Lembaga Pemerintah Non Kementerian, Badan Otorita, Badan Usaha Milik Negara, Badan Usaha Milik Daerah, Pemerintah Provinsi, Pemerintah Kabupaten/ Kota, badan keagamaan, badan sosial, perusahaan swasta, dan masyarakat pada umumnya. Untuk melaksanakan kegiatan pembangunan tersebut dibutuhkan tanah sebagai wadah kegiatannya. Kebutuhan akan tanah terus meningkat seiring dengan meningkatnya kegiatan pembangunan, yang membawa konsekuensi semakin mahalnya atau semakin tingginya nilai tanah dan meningkatnya persaingan untuk mendapatkan tanah.

Tanah yang ada di perkotaan lebih dititikberatkan pada penggunaannya untuk keperluan mendirikan bangunan daripada untuk keperluan pertanian, peternakan, perikanan, dan perkebunan. Bangunan tersebut dapat berupa perumahan, toko, rumah toko (ruko), rumah kantor (rukan), rumah sakit, hotel, pabrik, gudang, gedung peribadatan, gedung pendidikan, gedung olahraga, gedung pertemuan, gedung perkantoran, pasar/ plaza/mall, terminal, dan pelabuhan. Tanah di perkotaan ada yang dikuasai oleh perseorangan, perusahaan swasta, Lembaga Negara, Kementerian, Lembaga Pemerintah Non Kementerian, Badan Usaha Milik Negara, Badan Usaha Milik Daerah, Pemerintah, Pemerintah Provinsi, Pemerintah Kabupaten/Kota, badan keagamaan, badan sosial. Tanah di perkotaan yang dikuasai oleh perseorangan atau badan hukum berstatus Hak Milik, Hak Guna Bangunan, Hak Pakai, dan Hak Pengelolaan.

Persediaan tanah di perkotaan sangat terbatas, sedangkan kebutuhan akan tanah sangat besar seiring dengan meningkatnya kegiatan pembangunan yang dilakukan oleh perseorangan atau badan hukum. Dalam keadaan seperti ini terjadi ketidakseimbangan antara persediaan tanah dengan permintaan akan tanah untuk berbagai macam kepentingan dan keperluan. Perolehan hak atas tanah untuk memenuhi kebutuhan pembangunan yang dilakukan oleh perusahaan swasta atau Pemerintah Daerah dapat ditempuh melalui pengadaan tanah dengan cara pelepasan hak atas tanah oleh pemegang hak atas tanah dengan pemberian ganti kerugian atas tanah, bangunan, tanaman, dan/atau benda-benda lain yang berkaitan dengan tanah.

Pembangunan yang dapat dilakukan oleh perusahaan swasta, Pemerintah, maupun Pemerintah Daerah terkait dengan terbatasnya persediaan tanah di perkotaan adalah pembangunan gedung bertingkat. Dengan pembangunan gedung bertingkat, penggunaan tanah akan lebih optimal, efektif, dan efisien serta pengembangan wilayah kota secara vertikal. Selain dengan pembangunan gedung bertingkat, upaya yang dapat dilakukan untuk memenuhi kebutuhan akan tanah sehingga kegiatan pembangunan dapat dilaksanakan adalah dengan mengubah wilayah pantai menjadi daratan baru. Upaya mengubah wilayah pantai menjadi daratan baru dikenal dengan kegiatan reklamasi pantai.

Reklamasi pantai dapat dilakukan oleh perusahaan swasta yang berbentuk Perseroan Terbatas (PT), Pemerintah Kabupaten/Kota, Badan Usaha Milik Negara, kerjasama antara perusahaan swasta dan Pemerintah Kabupaten/Kota, atau kerja sama antara perusahaan swasta dan Badan Usaha Milik Negara. Tanah hasil reklamasi pantai nantinya dapat dipergunakan untuk mendirikan bangunan yang bersifat komersial atau publik. Dari uraian pendahuluan di atas, masalah yang hendak dikaji dirumuskan sebagai berikut: Pertama, status hak atas tanah apa yang dapat diberikan kepada pihak yang melakukan reklamasi pantai? Kedua, bagaimana cara perolehan hak atas tanah oleh pihak yang melakukan reklamasi pantai?

\section{B. Pembahasan}

\section{Status Hak Atas Tanah yang Dapat Diberikan kepada Pihak yang Melakukan Reklamasi Pantai}

Hak atas tanah sebagai salah satu hak penguasaan atas tanah diatur dalam Undang-Undang Nomor 5 Tahun 1960 tentang Peraturan Dasar 
Pokok-Pokok Agraria, LNRI Tahun 1960 No. 104 - TLNRI No. 2043, yang diundangkan pada tanggal 24 September 1960. Undang-Undang ini lebih dikenal dengan sebutan Undang-Undang Pokok Agraria (UUPA). Tanggal diundangkannya UUPA menjadi tanda lahirnya (terbentuknya) Hukum Tanah Nasional, yang mencabut (menyatakan tidak berlaku) Hukum Tanah Kolonial yang bersifat dualisme hukum dan tidak menjamin kepastian hukum bagi rakyat Indonesia.

Tujuan diundangkan UUPA disebutkan dalam Penjelasan Umum UUPA, yaitu: Pertama, meletakkan dasar-dasar bagi penyusunan Hukum Agraria Nasional, yang akan merupakan alat untuk membawakan kemakmuran, kebahagiaan, dan keadilan bagi negara dan rakyat, terutama rakyat tani, dalam rangka masyarakat yang adil dan makmur; Kedua, meletakkan dasar-dasar untuk mengadakan kesatuan dan kesederhanaan dalam Hukum Pertanahan; dan Ketiga, meletakkan dasardasar untuk memberikan kepastian hukum mengenai hak-hak atas tanah bagi rakyat seluruhnya.

Upaya yang dapat dilakukan untuk mewujudkan tujuan UUPA, yaitu kemakmuran, kebahagiaan, dan keadilan bagi petani dapat terwujud apabila petani memiliki tanah pertanian yang cukup luasnya. Kesatuan Hukum Pertanahan dapat terwujud apabila hanya ada 1 (satu) Hukum Pertanahan yang diatur dalam UUPA dan peraturan pelaksanaannya. Kesederhanaan Hukum Pertanahan dapat terwujud apabila Hukum Pertanahan tersebut mudah dipahami oleh rakyat Indonesia. Jaminan kepastian hukum mengenai hak-hak atas tanah dapat terwujud apabila diadakan pendaftaran tanah yang bersifat rechtscadaster.

Hak atas tanah bersumber dari hak menguasai negara atas tanah. Hal ini ditegaskan dalam Pasal 4 ayat(1)UUPA, yaitu atas dasar hak menguasai negara ditentukan macam-macam hak atas permukaan bumi, yang disebut tanah, yang dapat diberikan kepada orang-orang baik sendiri maupun bersama- sama dengan orang lain serta badan hukum. Atas dasar hak menguasai, negara menetapkan macammacam hak atas permukaan bumi atau hak atas tanah, yang dapat diberikan kepada orang-orang baik sendiri maupun bersama-sama dengan orang lain yang berasal dari warga negara Indonesia atau orang asing yang berkedudukan di Indonesia, badan hukum yang didirikan menurut hukum Indonesia dan berkedudukan di Indonesia, atau badan hukum asing yang mempunyai perwakilan di Indonesia.

Hak menguasai negara ditetapkan dalam Pasal 2 ayat (1) UUPA, yaitu negara sebagai organisasi kekuasaan seluruh rakyat pada tingkatan tertinggi menguasai bumi, air, dan ruang angkasa, termasuk kekayaan alam yang terkandung di dalamnya. Pasal 2 ayat (2) UUPA menetapkan berdasar hak menguasai, negara mempunyai wewenang, yaitu: Pertama, mengatur dan menyelenggarakan peruntukan, penggunaan, persediaan, dan pemeliharaan bumi, air, dan ruang angkasa; Kedua, menentukan dan mengatur hubunganhubungan hukum antara orang-orang dengan bumi, air, dan ruang angkasa; dan Ketiga, menentukan dan mengatur hubungan-hubungan hukum antara orang-orang dan perbuatan-perbuatan hukum yang mengenai bumi, air, ruang angkasa.

Pasal 4 ayat (1) UUPA menetapkan bahwa hak atas tanah permukaan bumi sama dengan hak atas tanah. Namun, UUPA tidak memberikan pengertian yang dimaksud dengan hak atas tanah. Boedi Harsono menyatakan bahwa hak atas tanah adalah hak atas sebagian tertentu permukaan bumi, yang berbatas, berdimensi dua dengan ukuran panjang dan lebar. ${ }^{1}$ Maria S.W. Sumardjono menyatakan bahwa hak atas tanah didefinisikan sebagai hak atas permukaan bumi yang memberi wewenang kepada pemegangnya untuk menggunakan tanah yang bersangkutan beserta tubuh bumi, air, serta ruang yang ada di atasnya. ${ }^{2}$ Ada persamaan pengertian hak atas tanah yang dikemukakan oleh Boedi Harsono dan Maria S.W. Sumardjono yaitu hak atas tanah

Boedi Harsono, 2003, Hukum Agraria Indonesia Sejarah Pembentukan Undang-Undang Pokok Agraria Isi, dan Pelaksanaannya, Djambatan, Jakarta, hlm. 18 .

Maria S.W. Sumardjono, 2008, Tanah dalam Perspektif Hak Ekonomi Sosial dan Budaya, Penerbit Kompas, Jakarta, hlm. 128. 
adalah hak atas permukaan bumi. Pengertian hak atas tanah yang dikemukakan oleh Boedi Harsono dan Maria S.W. Sumardjono mempunyai perbedaan, yaitu menurut Boedi Harsono, dalam hak atas tanah terdapat ukuran panjang dan lebar, sedangkan menurut Maria S.W. Sumardjono, dalam hak atas tanah terdapat wewenang bagi pemegang haknya yaitu menggunakan tanah yang bersangkutan beserta tubuh bumi, air, serta ruang yang ada di atasnya. Urip Santoso menyatakan bahwa hak atas tanah adalah hak yang memberikan wewenang kepada pemegang haknya untuk menggunakan dan atau mengambil manfaat dari tanah yang dihaki. Perkataan menggunakan mengandung pengertian bahwa hak atas tanah untuk keperluan mendirikan bangunan, sedangkan perkataan mengambil manfaat mengandung pengertian bahwa hak atas tanah untuk keperluan pertanian, perikanan, peternakan, dan perkebunan. ${ }^{3}$

Wewenang dalam hak atas tanah ditetapkan dalam Pasal 4 ayat (2) UUPA, yaitu menggunakan tanah yang bersangkutan, termasuk pula tubuh bumi dan ruang serta ruang yang ada di atasnya sekadar diperlukan untuk kepentingan yang langsung berhubungan dengan penggunaan tanah itu dalam batas-batas menurut Undang-Undang ini dan peraturan-peraturan hukum lain yang lebih tinggi. Soedikno Mertokusumo menyatakan bahwa wewenang yang dipunyai pemegang hak atas tanah terhadap tanahnya dibagi menjadi 2 (dua), yaitu: Pertama, wewenang umum, yaitu wewenang yang bersifat umum yaitu menggunakan tanah yang bersangkutan, termasuk pula tubuh bumi dan ruang serta ruang yang ada di atasnya sekadar diperlukan untuk kepentingan yang langsung berhubungan dengan penggunaan tanah itu dalam batas-batas menurut Undang-Undang ini dan peraturanperaturan hukum lain yang lebih tinggi. Kedua, wewenang khusus, yaitu wewenang yang bersifat khusus yaitu pemegang hak atas tanah mempunyai wewenang untuk menggunakan tanahnya sesuai dengan macam hak atas tanah, misalnya wewenang pada Hak Milik adalah dapat untuk keperluan pertanian dan/atau mendirikan bangunan, wewenang pada Hak Guna Bangunan adalah menggunakan tanah hanya untuk keperluan mendirikan bangunan, wewenang pada Hak Guna Bangunan adalah menggunakan tanah untuk keperluan pertanian, perikanan, peternakan, dan perkebunan. ${ }^{4}$

Hak atas permukaan bumi atau hak atas tanah yang disebutkan dalam Pasal 4 ayat (1) UUPA dijabarkan macamnya dalam Pasal 16 ayat (1) UUPA dan Pasal 53 ayat (1) UUPA. Sri Hajati menyatakan bahwa hak atas tanah dibedakan menjadi 3 (tiga) kelompok, yaitu: Pertama, hak atas tanah yang bersifat tetap. Hak atas tanah yang bersifat tetap adalah hak atas tanah yang akan tetap ada selama UUPA masih berlaku atau belum dicabut dengan Undang-Undang yang baru. Macam hak atas tanah yang bersifat tetap adalah Hak Milik, Hak Guna Usaha, Hak Guna Bangunan, Hak Pakai, Hak Sewa Untuk Bangunan, Hak Membuka Tanah, dan Hak Memungut Hasil Hutan. Kedua, hak atas tanah yang akan ditetapkan dengan UndangUndang. Hak atas tanah yang akan ditetapkan dengan Undang-Undang, adalah hak atas tanah yang akan lahir kemudian, yang akan ditetapkan dengan Undang-Undang. Macam hak atas tanah ini belum ada. Ketiga, hak atas tanah yang bersifat sementara. Hak atas tanah yang bersifat sementara adalah hak atas tanah yang dalam waktu yang singkat akan dihapuskan dikarenakan mengandung sifat-sifat pemerasan, mengandung sifat feodal, dan bertentangan dengan jiwa UUPA. Macam hak atas tanah ini adalah Hak Gadai, Hak Usaha Bagi Hasil, Hak Menumpang, dan Hak Sewa Tanah Pertanian. ${ }^{5}$

Dari segi asal tanahnya, hak atas tanah dibedakan menjadi 2 (dua) kelompok, yaitu: Pertama, hak atas tanah yang bersifat primer. Hak atas tanah yang bersifat primer adalah hak atas

Urip Santoso, 2013, Hukum Agraria Kajian Komprehensif, Kencana Prenada Media, Jakarta, hlm. 84.

Sudikno Mertokusumo, 1988, Hukum dan Politik Agraria, Universitas Terbuka - Karunika, Jakarta, hlm. 445.

Sri Hajati, "Restrukturisasi Hak Atas Tanah dalam Rangka Pembaruan Hukum Agraria Nasional", Naskah Pidato, disampaikan dalam acara Penerimaan Jabatan Guru Besar, Fakultas Hukum Universitas Airlangga, Surabaya, 5 Maret 2005, hlm. 9. 
tanah yang berasal dari tanah negara. Macam hak atas tanah ini adalah Hak Milik, Hak Guna Usaha, Hak Guna Bangunan atas tanah negara, dan Hak Pakai atas tanah negara. Kedua, hak atas tanah yang bersifat sekunder. Hak atas tanah yang bersifat sekunder adalah hak atas tanah yang berasal dari tanah pihak lain. Macam hak atas tanah ini adalah Hak Guna Bangunan atas tanah Hak Pengelolaan, Hak Guna Bangunan atas tanah Hak Milik, Hak Pakai atas tanah Hak Pengelolaan, Hak Pakai atas tanah Hak Milik, Hak Sewa Untuk Bangunan, Hak Gadai, Hak Usaha Bagi Hasil, Hak Menumpang, dan Hak Sewa Tanah Pertanian. ${ }^{6}$

Terjadinya hak atas tanah oleh perseorangan atau badan hukum dapat melalui 2 (dua) cara, yaitu: Pertama, originair. Perolehan hak atas tanah ini terjadi untuk pertama kali melalui Penetapan Pemerintah, atau karena ketentuan Undang-Undang (penegasan Konversi). Hak atas tanah yang lahir melalui Penetapan Pemerintah adalah Hak Milik yang berasal dari tanah negara, Hak Guna Usaha, Hak Guna Bangunan atas tanah negara, Hak Guna Bangunan atas tanah Hak Pengelolaan, Hak Pakai atas tanah negara, dan Hak Pakai atas tanah Hak Pengelolaan, Hak atas tanah yang lahir karena ketentuan Undang-Undang (penegasan konversi) adalah Hak Milik yang berasal dari konversi bekas tanah milik adat. Kedua, derivatif. Perolehan hak atas tanah ini terjadi dari tanah yang dimiliki atau dikuasai oleh pihak lain melalui peralihan hak atas tanah. Perolehan hak atas tanah dapat terjadi melalui pemindahan hak atas tanah dalam bentuk jual beli, tukar menukar, hibah, pemasukan dalam modal perusahaan (inbreng), dan lelang. Perolehan hak atas tanah juga dapat terjadi melalui beralih dalam bentuk pewarisan. ${ }^{7}$

Ada 4 (empat) cara perolehan hak atas tanah yang diatur dalam peraturan perundang-undangan, yaitu: Pertama, penetapan pemerintah. Perolehan hak atas tanah ini berasal dari tanah negara atau Hak Pengelolaan melalui Penetapan Pemerintah dalam bentuk Surat Keputusan Pemberian Hak. Kedua, ketentuan undang-undang (penegasan konversi). Perolehan hak atas tanah ini terjadi karena ketentuan Undang-Undang melalui permohonan penegasan konversi yang berasal dari bekas tanah milik adat. Ketiga, peralihan hak, perolehan hak atas tanah ini terjadi dalam bentuk beralih melalui pewarisan, dan dalam bentuk dialihkan melalui jual beli, tukar menukar, hibah, pemasukan dalam modal perusahaan (inbreng), dan lelang. Keempat, pemberian hak. Perolehan Hak Guna Bangunan atau Hak Pakai atas tanah Hak Milik yang dibuktikan dengan Akta Pemberian Hak Guna Bangunan atau Hak Pakai atas tanah Hak Milik yang dibuat oleh Pejabat Pembuat Akta Tanah (PPAT).

Subjek hak atas tanah atau pemegang hak atas tanah adalah orang dan badan hukum yaitu: Pertama, perseorangan, meliputi warga negara Indonesia dan orang asing yang berkedudukan di Indonesia. Kedua, badan hukum, meliputi Lembaga Negara, Kementerian, Lembaga Pemerintah Non Kementerian, Badan Otorita, Pemerintah Provinsi, Pemerintah Kabupaten/Kota, Pemerintahan Desa, Badan Usaha Milik Negara, Badan Usaha Milik Daerah, Badan Keagamaan, Badan Sosial, Badan Hukum Asing Yang Mempunyai Perwakilan Di Indonesia, Perseroan Terbatas, Perwakilan Negara Asing, dan Perwakilan Badan Internasional.

Berdasarkan aspek penggunaan atau pemanfaatan tanah, hak atas tanah dibagi menjadi 2 (dua) macam, yaitu: Pertama, hak atas tanah untuk keperluan mendirikan bangunan. Hak atas tanah untuk keperluan mendirikan bangunan, yaitu untuk rumah tempat tinggal, rumah toko, rumah kantor, rumah susun (apartemen), rumah sakit, toko, kantor, pabrik, gudang, hotel, pasar/plaza/mall, gedung pendidikan, gedung olahraga, gedung pertemuan, gedung peribadatan, terminal, pelabuhan, bandar udara. Kedua, hak atas tanah untuk keperluan bukan mendirikan bangunan. Hak atas tanah untuk keperluan bukan mendirikan bangunan, yaitu untuk

Urip Santoso, Op.cit., hlm. 91.

Urip Santoso, 2011, Perolehan Hak Atas Tanah, Revka Petra Media, Surabaya, hlm. 19 - 20. 
pertanian, perikanan, peternakan, dan perkebunan.

Berdasarkan aspek masa penguasaan hak atas tanahnya, hak atas tanah dibagi menjadi 3 (tiga) macam, yaitu: Pertama, hak atas tanah tidak berjangka waktu tertentu. Hak atas tanah tidak berjangka waktu tertentu, yakni Hak Milik. Kedua, hak atas tanah berjangka waktu tertentu. Hak atas tanah berjangka waktu tertentu, adalah Hak Guna Usaha, Hak Guna Bangunan, Hak Pakai yang bersifat privat, dan Hak Sewa Untuk Bangunan. Ketiga, hak atas tanah yang berlaku selama tanahnya dipergunakan untuk pelaksanaan tugasnya. Hak atas tanah yang berlaku selama tanahnya dipergunakan untuk pelaksanaan tugasnya, adalah Hak Pakai yang dikuasai oleh Lembaga Negara, Kementerian, Lembaga Pemerintah Non Kementerian, Pemerintah Provinsi, Pemerintah Kabupaten/Kota, Pemerintahan Desa, Badan Otorita, Badan Usaha Milik Negara, Badan Usaha Milik Daerah, Badan Keagamaan, Badan Sosial, Perwakilan Negara Asing, dan Perwakilan Badan Internasional.

Untuk melaksanakan kegiatan pembangunan dibutuhkan tanah sebagai wadah kegiatannya. Tanah yang diperoleh pelaku pembangunan dapat berasal dari reklamasi pantai. Tanah yang diperoleh melalui reklamasi pantai dapat ditujukan untuk kepentingan umum dan/atau kepentingan komersial. Pihak yang berinisiatif untuk melakukan reklamasi pantai, adalah: Pertama, perusahaan swasta. Kalau inisiatif reklamasi pantai berasal dari perusahaan swasta yang berbentuk Perseroan Terbatas (PT), maka semua kegiatan reklamasi pantai dilakukan oleh perusahaan swasta. Kedua, Pemerintah Kabupaten/Kota. Kalau inisiatif reklamasi pantai berasal dari Pemerintah Kabupaten/Kota, maka semua kegiatan reklamasi pantai dilakukan oleh Pemerintah Kabupaten/Kota. Ketiga, Badan Usaha Milik Negara (BUMN). Kalau inisiatif reklamasi pantai berasal dari Badan Usaha Milik Negara yang berbentuk Perusahaan Perseroan (PT Persero), maka semua kegiatan reklamasi pantai dilakukan oleh Perusahaan Perseroan (PT Persero). Keempat, kerjasama perusahaan swasta dan Pemerintah Kabupaten/Kota. Kalau inisiatif reklamasi pantai berasal dari kerjasama antara perusahaan swasta yang berbentuk Perseroan Terbatas (PT) dan Pemerintah Kabupaten/Kota, maka semua kegiatan reklamasi pantai dapat dilakukan oleh Perseroan Terbatas (PT) atas dasar perjanjian dengan Pemerintah Kabupaten/Kota. Kelima, kerjasama Badan Usaha Milik Negara dan perusahaan swasta. Kalau inisiatif reklamasi pantai berasal dari kerjasama antara perusahaan swasta yang berbentuk Perseroan Terbatas (PT) dan Badan Usaha Milik Negara, maka semua kegiatan reklamasi pantai dapat dilakukan oleh Perseroan Terbatas (PT) atas dasar perjanjian dengan Badan Usaha Milik Negara.

Status hak atas tanah yang dapat diberikan kepada pihak yang melakukan reklamasi pantai, yaitu: Pertama, perusahaan swasta yang berbentuk Perseroan Terbatas (PT). Kalau pihak yang melakukan reklamasi pantai adalah perusahaan swasta yang berbentuk Perseroan Terbatas (PT), maka hak atas tanah yang dapat diperoleh berupa Hak Guna Bangunan atau Hak Pakai. Dalam UUPA dan Peraturan Pemerintah Nomor 40 Tahun 1996 tentang Hak Guna Usaha, Hak Guna Bangunan, dan Hak Pakai Atas Tanah ditegaskan Perseroan Terbatas (PT) sebagai badan hukum yang didirikan menurut hukum Indonesia dan berkedudukan di Indonesia dapat menguasai tanah berstatus Hak Guna Bangunan atau Hak Pakai. Kalau hak atas tanah yang diperoleh adalah Hak Guna Bangunan, maka masa penguasaannya adalah untuk pertama kali berjangka waktu paling lama 30 (tiga puluh) tahun, dapat diperpanjang untuk jangka waktu paling lama 20 (dua puluh) tahun, dan dapat diperbaharui haknya untuk jangka waktu paling lama 30 (tiga puluh) tahun. Kalau hak atas tanah yang diperoleh adalah Hak Pakai, maka masa penguasaannya adalah untuk pertama kali berjangka waktu paling lama 25 (dua puluh lima) tahun, dapat diperpanjang untuk jangka waktu paling lama 20 (dua puluh) tahun, dan dapat diperbaharui haknya untuk jangka waktu paling lama 25 (dua puluh lima) tahun. Kedua, Pemerintah Kabupaten/Kota. Kalau pihak yang melakukan reklamasi pantai adalah Pemerintah Kabupaten/ 
Kota, maka hak atas tanah yang diperoleh adalah Hak Pakai atau Hak Pengelolaan. Dalam UUPA, Peraturan Pemerintah No. 40 Tahun 1996, dan Peraturan Menteri Negara Agraria/Kepala Badan Pertanahan Nasional No. 9 Tahun 1999 tentang Tata Cara Pemberian dan Pembatalan Pemberian Hak Atas Tanah dan Hak Pengelolaan ditegaskan bahwa Pemerintah Kabupaten/Kota dapat menguasai tanah berstatus Hak Pakai. Dalam Peraturan Menteri Negara Agraria/Kepala Badan Pertanahan Nasional No. 9 Tahun 1999 ditegaskan bahwa Pemerintah Kabupaten/Kota dapat menguasai tanah berstatus Hak Pengelolaan. Kalau status hak atas tanah yang diperoleh Pemerintah Kabupaten/Kota berupa Hak Pakai, maka masa penguasaannya berlaku selama tanah Hak Pakai dipergunakan untuk keperluan pelaksanaan tugasnya dan kewenangannya hanyalah mempergunakan tanah Hak Pakai untuk keperluan pelaksanaan tugasnya. Kalau status hak atas tanah yang diperoleh Pemerintah Kabupaten/Kota berupa Hak Pengelolaan, maka masa penguasaannya berlaku selama tanah Hak Pengelolaan dipergunakan untuk keperluan pelaksanaan tugasnya dan kewenangannya dapat menyerahkan bagian-bagian tanah Hak Pengelolaan kepada pihak ketiga dan atau bekerja sama dengan pihak ketiga. Ketiga, Badan Usaha Milik Negara. Kalau pihak yang melakukan reklamasi pantai adalah Badan Usaha Milik Negara, maka hak atas tanah yang diperoleh adalah Hak Pakai atau Hak Pengelolaan. Dalam UUPA, Peraturan Pemerintah No. 40 Tahun 1996, dan Peraturan Menteri Negara Agraria/Kepala Badan Pertanahan Nasional No. 9 Tahun 1999 ditegaskan bahwa Badan Usaha Milik Negara sebagai badan hukum yang didirikan menurut hukum Indonesia dan berkedudukan di Indonesia dapat menguasai tanah berstatus Hak Pakai. Dalam Peraturan Menteri Negara Agraria/ Kepala Badan Pertanahan Nasional No. 9 Tahun 1999 ditegaskan bahwa Badan Usaha Milik Negara dapat menguasai tanah berstatus Hak Pengelolaan. Kalau status hak atas tanah yang diperoleh Badan Usaha Milik Negara berupa Hak Pakai, maka masa penguasaannya berlaku selama tanah Hak Pakai dipergunakan untuk keperluan pelaksanaan tugasnya dan kewenangannya hanyalah mempergunakan tanah Hak Pakai untuk keperluan pelaksanaan tugasnya. Kalau status hak atas tanah yang diperoleh Badan Usaha Milik Negara berupa Hak Pengelolaan, maka masa penguasaannya berlaku selama tanah Hak Pengelolaan dipergunakan untuk keperluan pelaksanaan tugasnya dan kewenangannya dapat menyerahkan bagian-bagian tanah Hak Pengelolaan kepada pihak ketiga dan atau bekerja sama dengan pihak ketiga. Keempat, kerjasama antara Perseroan Terbatas dan Pemerintah Kabupaten/Kota. Kalau pihak yang melakukan reklamasi pantai adalah kerjasama antara Perseroan Terbatas dan Pemerintah Kabupaten/Kota, maka hak atas tanah yang diperoleh semula adalah Hak Pengelolaan atas nama Pemerintah Kabupaten/Kota. Selanjutnya dibuatkan Perjanjian Penggunaan Tanah (PPT) antara Perseroan Terbatas dan Pemerintah Kabupaten/Kota yang dibuktikan dengan akta notaris, yang isinya adalah Perseroan Terbatas akan mendapatkan Hak Guna Bangunan yang berasal dari tanah Hak Pengelolaan atas nama Pemerintah Kabupaten/Kota. Perolehan Hak Guna Bangunan atas tanah Hak Pengelolaan melalui Penetapan Pemerintah dalam bentuk Surat Keputusan Pemberian Hak (SKPH) yang diterbitkan oleh Kepala Kantor Pertanahan Kabupaten/Kota. Hak Guna Bangunan atas tanah Hak Pengelolaan yang diperoleh Perseroan Terbatas, untuk pertama kali berjangka waktu paling lama 30 (tiga puluh) tahun, dapat diperpanjang untuk jangka waktu paling lama 20 (dua puluh) tahun, dan dapat diperbaharui haknya untuk jangka waktu paling lama 30 (tiga puluh) tahun. Perpanjangan jangka waktu dan pembaharuan Hak Guna Bangunan atas tanah Hak Pengelolaan dapat dilakukan setelah mendapatkan persetujuan secara tertulis dari pemegang Hak Pengelolaan. Kelima, kerjasama antara Perseroan Terbatas dan Badan Usaha Milik Negara. Kalau pihak yang melakukan reklamasi pantai adalah kerjasama antara Perseroan Terbatas dan Badan Usaha Milik Negara, maka hak atas tanah yang diperoleh semula adalah Hak Pengelolaan atas 
nama Badan Usaha Milik Negara. Selanjutnya dibuatkan Perjanjian Penggunaan Tanah (PPT) antara Perseroan Terbatas dan Badan Usaha Milik Negara yang dibuktikan dengan akta notaris, yang isinya adalah Perseroan Terbatas akan mendapatkan Hak Guna Bangunan yang berasal dari tanah Hak Pengelolaan atas nama Badan Usaha Milik Negara. Perolehan Hak Guna Bangunan atas tanah Hak Pengelolaan melalui Penetapan Pemerintah dalam bentuk Surat Keputusan Pemberian Hak (SKPH) yang diterbitkan oleh Kepala Kantor Pertanahan Kabupaten/Kota. Hak Guna Bangunan atas tanah Hak Pengelolaan yang diperoleh Perseroan Terbatas, untuk pertama kali berjangka waktu paling lama 30 (tiga puluh) tahun, dapat diperpanjang untuk jangka waktu paling lama 20 (dua puluh) tahun, dan dapat diperbaharui haknya untuk jangka waktu paling lama 30 (tiga puluh) tahun. Perpanjangan jangka waktu dan pembaharuan Hak Guna Bangunan atas tanah Hak Pengelolaan dapat dilakukan setelah mendapatkan persetujuan secara tertulis dari pemegang Hak Pengelolaan.

\section{Cara Perolehan Hak Atas Tanah oleh} Pihak yang Melakukan Reklamasi Pantai

Peraturan perundang-undangan yang terkait dengan perolehan tanah yang berasal dari reklamasi pantai, adalah Undang-Undang No. 5 Tahun 1960 tentang Peraturan Dasar Pokok-pokok Agraria, Undang-Undang No. 26 Tahun 2007 tentang Penataan Ruang, Undang-Undang No. 27 Tahun 2007 tentang Pengelolaan Wilayah Pesisir dan Pulau-pulau Kecil, Undang-Undang No. 23 Tahun 2014 tentang Pemerintahan Daerah, Peraturan Pemerintah No. 40 Tahun 1996 tentang Hak Guna Usaha, Hak Guna Bangunan, dan Hak Pakai Atas Tanah, Peraturan Pemerintah No. 24 Tahun 1997 tentang Pendaftaran Tanah, Peraturan Pemerintah No. 16 Tahun 2004 tentang Penatagunaan Tanah, Peraturan Pemerintah No. 38 Tahun 2007 tentang Pembagian Urusan Pemerintahan Antara Pemerintah, Pemerintah Daerah Provinsi, dan Pemerintah Daerah Kabupaten/Kota, Keputusan Presiden No. 34 Tahun 2003 tentang Kebijakan Nasional di Bidang Pertanahan, Peraturan Menteri
Negara Agraria/Kepala Badan Pertanahan Nasional No. 9 Tahun 1999 tentang Izin Lokasi, Peraturan Menteri Negara Agraria/Kepala Badan Pertanahan Nasional No. 9 Tahun 1999, dan Peraturan Kepala Badan Pertanahan Nasional RI No. 2 Tahun 2013 tentang Pelimpahan Kewenangan Pemberian Hak Atas Tanah dan Kegiatan Pendaftaran Tanah.

Pengertian reklamasi disebutkan dalam Pasal 1 angka 23 Undang-Undang No. 27 Tahun 2007, yaitu kegiatan yang dilakukan oleh orang dalam rangka meningkatkan manfaat sumber daya lahan ditinjau dari sudut lingkungan dan sosial ekonomi dengan cara pengurusan, pengeringan lahan atau drainase. Lebih lanjut dalam Pasal 34 Undang-Undang No. 27 Tahun 2007 dinyatakan bahwa: Pertama, reklamasi wilayah pesisir dan pulau-pulau kecil dilakukan dalam rangka meningkatkan manfaat dan/atau nilai tambah wilayah pesisir dan pulaupulau kecil ditinjau dari aspek teknis, lingkungan, dan sosial ekonomi; Kedua, pelaksanaan reklamasi sebagaimana dimaksud pada ayat (1) wajib menjaga dan memperhatikan: (a) keberlanjutan kehidupan dan penghidupan masyarakat; dan (b) keseimbangan antara kepentingan pemanfaatan dan kelestarian fungsi lingkungan pesisir dan pulaupulau kecil; dan (c) persyaratan teknis pengambilan, pengerukan, dan penimbunan material; dan Ketiga, perencanaan dan pelaksanaan reklamasi diatur lebih lanjut dengan Peraturan Presiden.

Pasal 12 Peraturan Pemerintah No. 16 Tahun 2004 menyatakan bahwa tanah yang berasal dari tanah timbul atau hasil reklamasi di wilayah perairan pantai, pasang surut rawa, danau, dan bekas sungai dikuasai langsung oleh negara. Penjelasan Pasal 12 Peraturan Pemerintah No. 16 Tahun 2004 menyatakan bahwa tanah timbul adalah daratan yang terbentuk secara alami maupun buatan karena proses pengendapan di sungai, danau, pantai, dan atau pulau timbul, serta penguasaan tanahnya dikuasai negara, sedangkan reklamasi adalah pengurusan wilayah perairan guna memperluas ruang daratan, penggunaan, dan pemanfaatan tanahnya harus sesuai dengan Rencana Tata Ruang Wilayah (RTRW). Reklamasi 
adalah kegiatan yang dilakukan oleh orang sesuai dan berdasar kepada Rencana Tata Ruang Wilayah (RTRW) yang telah ditetapkan melalui pengurusan wilayah perairan (pantai) guna memperluas ruang darat yang berorientasi pada kepentingan umum dan atau kepentingan komersial.

Peraturan yang mengatur penyediaan tanah hasil reklamasi diatur dalam Surat Edaran Kepala Badan Pertanahan Nasional No. 410 - 1293 tanggal 9 Mei 1996 dan No. 440 - 3725 tanggal 9 November 1996 tentang Tata Cara Penyediaan Tanah Non Pertanian Dengan Cara Reklamasi Pantai. Dalam Surat Edaran Kepala Badan Pertanahan Nasional tersebut dinyatakan bahwa status tanah hasil reklamasi dinyatakan sebagai tanah yang dikuasai langsung oleh negara, sementara pihak yang melakukan reklamasi mendapatkan prioritas untuk mengajukan permohonan pemberian hak atas tanah hasil reklamasi tersebut.

Undang-Undang No. 26 Tahun 2007 menetapkan bahwa kegiatan pembangunan yang dilakukan oleh siapapun harus sesuai dan berdasar kepada Rencana Tata Ruang Wilayah (RTRW) yang telah ditetapkan. Kegiatan reklamasi pantai harus sesuai dan berdasar kepada Rencana Tata Ruang Wilayah (RTRW) yang telah ditetapkan dalam bentuk Peraturan Daerah Kabupaten/Kota. Kalau kegiatan reklamasi pantai tidak sesuai dengan Rencana Tata Ruang Wilayah (RTRW) yang telah ditetapkan, maka seharusnya kegiatan reklamasi pantai itu tidak dilakukan. Kalau kegiatan reklamasi pantai tidak sesuai dengan Rencana Tata Ruang Wilayah (RTRW) yang telah ditetapkan, maka seharusnya terlebih dahulu dilakukan peninjauan kembali terhadap Peraturan Daerah Kabupaten/ Kota yang menetapkan Rencana Tata Ruang Wilayah (RTRW).

Ruang darat baru atau tanah baru yang berasal dari reklamasi pantai yang dilakukan oleh pihak yang melakukan reklamasi pantai, status tanahnya adalah tanah negara atau tanah yang dikuasai langsung oleh negara. Pihak yang melakukan reklamasi pantai diberikan prioritas untuk mendapatkan hak atas tanah melalui permohonan pemberian hak atas tanah negara kepada Kepala Badan Pertanahan Nasional Republik Indonesia melalui Kepala Kantor Pertanahan Kabupaten/Kota. Perolehan hak atas tanah yang berasal dari tanah negara melalui Penetapan Pemerintah dalam bentuk Surat Keputusan Pemberian Hak (SKPH) yang diterbitkan oleh Kepala Badan Pertanahan Nasional Republik Indonesia, atau pejabat Badan Pertanahan Nasional Republik Indonesia yang diberikan pelimpahan kewenangan untuk memberikan hak atas tanah. Yang dimaksud dengan Penetapan Pemerintah dalam perolehan hak atas tanah adalah suatu keputusan untuk memberikan hak atas tanah yang diterbitkan oleh Kepala Badan Pertanahan Nasional Republik Indonesia, atau pejabat Badan Pertanahan Nasional Republik Indonesia yang diberikan pelimpahan kewenangan untuk memberikan hak atas tanah.

Menurut Boedi Harsono, yang dimaksud tanah negara atau tanah yang dikuasai langsung oleh negara adalah tanah yang tidak dipunyai dengan sesuatu hak atas tanah. ${ }^{8}$ Arie S. Hutagalung menyatakan bahwa tanah negara adalah tanah yang masih langsung dikuasai oleh negara yang di atasnya belum dihaki dengan hak-hak perseorangan yang diberikan kepada badan hukum, perseorangan, termasuk instansi Pemerintah. ${ }^{9}$ Tanah negara atau tanah yang dikuasai langsung oleh negara adalah tanah yang di atasnya belum terdapat atau belum dibebani dengan hak atas tanah tertentu atau tanah yang di atasnya tidak ada hak yang bersifat perseorangan yang dimiliki atau dikuasai oleh orang per orang atau badan hukum. Pengertian tanah negara menurut Pasal 1 angka 3 Peraturan Pemerintah No. 24 Tahun 1997, adalah tanah yang tidak dipunyai dengan sesuatu hak atas tanah. Pengertian tanah negara menurut Pasal 1 ayat (2) Peraturan Menteri

Boedi Harsono, Op.cit., hlm. 480.

Arie S. Hutagalung, 2002, Serba Aneka Masalah Tanah dalam Kegiatan Ekonomi, Badan Penerbit Fakultas Hukum Universitas Indonesia, Jakarta, hlm. 62 . 
Negara Agraria/Kepala Badan Pertanahan Nasional No. 9 Tahun 1999, adalah tanah yang dikuasai oleh negara sebagaimana dimaksud dalam UndangUndang Nomor 5 Tahun 1960 tentang Peraturan Dasar Pokok-pokok Agraria.

Tanah yang dapat dikategorikan sebagai tanah negara atau tanah yang dikuasai langsung oleh negara, adalah: (a) hak atas tanah bekas hak barat yang tidak diajukan penegasan konversi hingga tanggal 24 September 1980; (b) hak atas tanah yang pemegang haknya atau subjek haknya tidak lagi memenuhi syarat sebagai pemegang hak atas tanah atau subjek hak atas tanah; (c) hak atas tanah yang dilepaskan oleh pemegang haknya untuk kepentingan pihak lain; (d) hak atas tanah yang dicabut untuk kepentingan umum; (e) hak atas tanah yang ditelantarkan oleh pemegang haknya; (f) Hak Guna Usaha, Hak Guna Bangunan, atau Hak Pakai yang berakhir jangka waktunya, tetapi tidak diperpanjang jangka waktunya oleh pemegang haknya; (g) Hak Guna Usaha, Hak Guna Bangunan, atau Hak Pakai yang berakhir jangka waktu perpanjangannya, tetapi tidak diperbaharui haknyanya oleh pemegang haknya; (h) Hak Milik, Hak Guna Usaha, Hak Guna Bangunan, atau Hak Pakai yang pemegang haknya meninggal dunia dan tidak meninggalkan ahli waris; (i) kawasan hutan yang dikeluarkan statusnya sebagai kawasan hutan; (j) tanah yang berasal dari reklamasi pantai; (k) tanah yang berasal dari hasil konsolidasi tanah; (l) tanah yang berasal dari ruislag; (m) tanah bekas tanah partikelir; (n) Hak Pengelolaan yang dilepaskan oleh pemegang haknya. ${ }^{10}$

Pihak yang melakukan reklamasi pantai dapat memperoleh hak atas tanah melalui permohonan pemberian hak atas tanah negara kepada Kepala Badan Pertanahan Nasional Republik Indonesia. Permohonan pemberian hak atas tanah diajukan kepada Kepala Badan Pertanahan Nasional Republik Indonesia melalui Kepala Kantor Pertanahan Kabupaten/Kota yang wilayah kerjanya meliputi letak tanah yang bersangkutan. Apabila permohonan pemberian hak atas tanah dikabulkan, maka diterbitkan Penetapan Pemerintah dalam bentuk Surat Keputusan Pemberian Hak (SKPH) oleh Kepala Badan Pertanahan Nasional Republik Indonesia, atau pejabat Badan Pertanahan Nasional Republik Indonesia yang diberikan pelimpahan kewenangan untuk memberikan hak atas tanah.

Pejabat Badan Pertanahan Nasional Republik Indonesia yang berwenang menerbitkan Surat Keputusan Pemberian Hak (SKPH) atas tanah yang berasal dari tanah negara, yaitu: Pertama, Kepala Kantor Pertanahan Kabupaten/Kota. Berdasarkan ketentuan Pasal 4 huruf b Peraturan Kepala Badan Pertanahan Nasional Republik Indonesia No. 2 Tahun 2013, Kepala Kantor Pertanahan Kabupaten/ Kota berwenang memberikan Hak Guna Bangunan untuk badan hukum atas tanah yang luasnya tidak lebih dari $20.000 \mathrm{~m}^{2}$ (dua puluh ribu meter persegi). Berdasarkan ketentuan Pasal 5 huruf c Peraturan Kepala Badan Pertanahan Nasional Republik Indonesia No. 2 Tahun 2013, Kepala Kantor Pertanahan Kabupaten/Kota berwenang memberikan Hak Pakai untuk badan hukum swasta, BUMN/BUMD atas tanah non pertanian yang luasnya tidak lebih dari $20.000 \mathrm{~m}^{2}$ (dua puluh ribu meter persegi). Berdasarkan ketentuan Pasal 5 huruf d Peraturan Kepala Badan Pertanahan Nasional Republik Indonesia No. 2 Tahun 2013, Kepala Kantor Pertanahan Kabupaten/Kota berwenang memberikan Hak Pakai aset Pemerintah Pusat dan Pemerintah Daerah. Kedua, Kepala Kantor Wilayah Badan Pertanahan Nasional Provinsi. Berdasarkan ketentuan Pasal 9 huruf b Peraturan Kepala Badan Pertanahan Nasional Republik Indonesia No. 2 Tahun 2013, Kepala Kantor Wilayah Badan Pertanahan Nasional berwenang memberikan Hak Guna Bangunan untuk badan hukum atas tanah yang luasnya lebih dari $20.000 \mathrm{~m}^{2}$ (dua puluh ribu meter persegi) dan tidak lebih dari $150.000 \mathrm{~m}^{2}$ (seratus lima puluh ribu meter persegi). Berdasarkan 
ketentuan Pasal 10 huruf c Peraturan Kepala Badan Pertanahan Nasional Republik Indonesia No. 2 Tahun 2013, Kepala Kantor Wilayah Badan Pertanahan Nasional berwenang memberikan Hak Pakai untuk badan hukum swasta, BUMN/BUMD atas tanah non pertanian yang luasnya lebih dari $20.000 \mathrm{~m}^{2}$ (dua puluh ribu meter persegi) dan tidak lebih dari $150.000 \mathrm{~m}^{2}$ (seratus lima puluh ribu meter persegi). Ketiga, Kepala Badan Pertanahan Nasional Republik Indonesia. Berdasarkan ketentuan Pasal 13 Peraturan Kepala Badan Pertanahan Nasional Republik Indonesia No. 2 Tahun 2013, Kepala Badan Pertanahan Nasional Republik Indonesia berwenang memberikan Hak Guna Bangunan dan Hak Pakai yang tidak dilimpahkan kewenangannya kepada Kepala Kantor Wilayah Badan Pertanahan Nasional Provinsi atau Kepala Kantor Pertanahan Kabupaten/Kota. Berdasarkan ketentuan Pasal 74 ayat (3) Peraturan Menteri Negara Agraria/ Kepala Badan Pertanahan Nasional No. 9 Tahun 1999, Kepala Badan Pertanahan Nasional Republik Indonesia berwenang memberikan Hak Pengelolaan.

Dalam waktu yang ditentukan dalam Surat Keputusan Pemberian Hak (SKPH), pihak yang melakukan reklamasi pantai sebagai pemohon pemberian hak atas tanah negara berkewajiban mendaftarkan Surat Keputusan Pemberian Hak (SKPH) kepada Kepala Kantor Pertanahan Kabupaten/Kota yang wilayah kerjanya meliputi letak tanah yang bersangkutan. Pendaftaran Surat Keputusan Pemberian Hak (SKPH) oleh pemohon pemberian hak atas tanah negara dengan maksud agar dicatat dalam Buku Tanah dan diterbitkan sertipikat sebagai surat tanda bukti hak oleh Kantor Pertanahan Kabupaten/Kota. Pendaftaran Surat Keputusan Pemberian Hak (SKPH) tersebut menjadi tanda lahirnya Hak Guna Bangunan, Hak Pakai, atau Hak Pengelolaan.

Pengertian sertipikat disebutkan dalam Pasal 1 angka 20 Peraturan Pemerintah No. 24 Tahun 1997, adalah surat tanda bukti hak sebagaimana dimaksud dalam Pasal 19 ayat (2) huruf c UUPA, untuk hak atas tanah, hak pengelolaan, tanah wakaf, hak milik atas satuan rumah susun dan hak tanggungan yang masing-masing sudah dibukukan dalam buku tanah yang bersangkutan. Sertipikat berfungsi sebagai surat tanda bukti hak. Dengan diterbitkan sertipikat, orang dengan mudah dapat membuktikan bahwa dirinya sebagai pemegang hak. Isi sertipikat adalah salinan buku tanah yang memuat data fisik dan data yuridis, dan surat ukur yang memuat data fisik.

\section{Penutup}

Pihak yang berinisiatif melakukan reklamasi pantai adalah perusahaan swasta, Pemerintah Kabupaten/Kota, Badan Usaha Milik Negara, kerja sama perusahaan swasta dan Pemerintah Kabupaten/ Kota, dan kerja sama perusahaan swasta dan Badan Usaha Milik. Hak atas tanah dapat diperoleh pihak yang melakukan reklamasi pantai adalah Hak Guna Bangunan, Hak Pakai, atau Hak Pengelolaan. Status tanah hasil reklamasi pantai adalah tanah negara atau tanah yang dikuasai langsung oleh negara. Untuk mendapatkan hak atas tanah yang berasal dari reklamasi pantai, pihak yang melakukan reklamasi pantai mengajukan permohonan pemberian hak atas tanah negara kepada Kepala Badan Pertanahan Nasional Republik Indonesia melalui Kepala Kantor Pertanahan Kabupaten/Kota yang wilayah kerjanya meliputi letak tanah yang bersangkutan. Atas permohonan tersebut diterbitkan Surat Keputusan Pemberian Hak (SKPH) oleh Kepala Badan Pertanahan Nasional Republik Indonesia, atau pejabat Badan Pertanahan Nasional Republik Indonesia yang diberikan pelimpahan kewenangan untuk memberikan hak atas tanah. Surat Keputusan Pemberian Hak (SKPH) tersebut didaftarkan oleh pihak yang melakukan reklamasi pantai kepada Kepala Kantor Pertanahan Kabupaten/Kota untuk dicatat dalam Buku Tanah dan diterbitkan sertipikat sebagai surat tanda bukti hak. 


\section{DAFTAR PUSTAKA}

\section{A. Buku}

Harsono, Boedi, 2003, Hukum Agraria Indonesia Sejarah Pembentukan Undang-Undang Pokok Agraria Isi, dan Pelaksanaannya, Djambatan, Jakarta.

Hutagalung, Arie S., 2002, Serba Aneka Masalah Tanah dalam Kegiatan Ekonomi, Badan Penerbit Fakultas Hukum Universitas Indonesia, Jakarta.

Mertokusumo, Sudikno, 1988, Hukum dan Politik Agraria, Universitas Terbuka - Karunika, Jakarta.

Santoso, Urip, 2013, Hukum Agraria Kajian Komprehensif, Kencana Prenada Media, Jakarta.
, 2013, Hukum Pengadaan Tanah Untuk Kepentingan Umum, Pusat Penerbitan dan Pencetakan UNAIR, Surabaya. 2011, Perolehan Hak Atas Tanah, Revka Petra Media, Surabaya.

Sumardjono, Maria S.W., 2008, Tanah dalam Perspektif Hak Ekonomi Sosial dan Budaya, Penerbit Kompas, Jakarta.

\section{B. Makalah}

Hajati, Sri, "Restrukturisasi Hak Atas Tanah dalam Rangka Pembaruan Hukum Agraria Nasional", Naskah Pidato, disampaikan dalam acara Penerimaan Jabatan Guru Besar, Fakultas Hukum Universitas Airlangga, Surabaya, 5 Maret 2005. 